\title{
Claas Cordemann
}

\section{Herders christlicher Monismus}

\section{Eine Studie zur Grundlegung von Johann Gottfried Herders Christologie und Humanitätsideal}

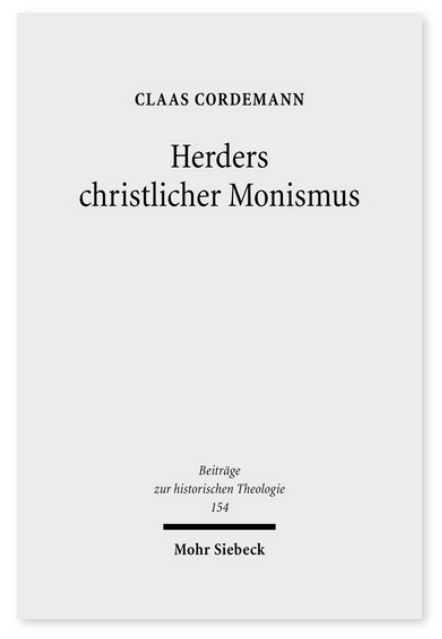

2010. XII, 310 Seiten. BHTh 154

ISBN 978-3-16-151064-9

DOI 10.1628/978-3-16-151064-9

eBook PDF 109,00€

ISBN 978-3-16-150408-2

Leinen $109,00 €$
Claas Cordemann stellt im interdisziplinären Diskurs mit der germanistischen und philosophischen Herderforschung den Theologen Herder ins Zentrum und zeigt inn als einen Denker von Rang, der die philosophische und theologische Debattenlage seiner Zeit aufgreift und produktiv weiterführt. Herders Denken wird in den philosophischen Diskurs des 18. Jahrhunderts eingebettet, der mit den Namen Descartes, Spinoza und Leibniz verbunden ist. Cordemann zeigt, dass Herder mit seinem Konzept eines »christlichen Monismus« die Grundeinsichten einer spinozanisch inspirierten Metaphysik mit den Grundanliegen christlicher Theologie zu verbinden sucht. Herders Natur-, Geschichts- und Kulturtheorie sowie seine Bestimmung des Menschen und der Menschheitsgeschichte, so die These der Arbeit, haben ihren Fokus in der Christologie und sind vom Gottesgedanken her zu verstehen.

Claas Cordemann Geboren 1971; Studium der Ev. Theologie in Göttingen und Halle/Saale; 2009 Promotion im Fach Systematische Theologie in Göttingen; seit 2016 als Oberkirchenrat zuständig für theologische Grundsatzfragen im Amt der VELKD.
Jetzt bestellen:

https://mohrsiebeck.com/buch/herders-christlicher-monismus-9783161510649?no_cache=1

order@mohrsiebeck.com

Telefon: +49 (0)7071-923-17

Telefax: +49(0)7071-51104 